\title{
EFFECTS OF PHYSICAL EXERCISE IN PATIENTS AFTER CARDIAC TRANSPLANTATION: A SYSTEMATIC REVIEW
}

\author{
Pedro Henrique Cerqueira de Andrade', André Luiz Lisboa Cordeiro ${ }^{2}$, Jefferson Petto ${ }^{3}$
}

Corresponding author: André Luiz Lisboa Cordeiro - andrelisboacordeiro@gmail.com 'Physiotherapist. Graduated in Hospital Physiotherapy focused on ICU at Hélio Rocha Faculty; IC Resident at the State University of Bahia, Salvador, Bahia, Brazil. ${ }^{2}$ Physiotherapist. Master's degree candidate in Medicine and Human Health at BAHIANA - School of Medicine and Human Health; Professor at Nobre Faculties, Feira de Santana, Bahia, Brazil. ${ }^{3}$ Physiotherapist. PhD in Medicine and Human Health. Professor at BAHIANA - School of Medicine and Human Health. President of the Scientific Comission of the Physiotherapy Department of the Brazilian Society of Cardiology, Salvador, Bahia, Brazil.

\begin{abstract}
Objective: To synthesize the main scientific evidences related to the effects of different protocols of therapy by exercise in patients submitted to cardiac transplantation. Methodology: The research was carried out from the databases MEDLINE and EMBASE via Ovid from 2000 until October 1, 2016, the accumulated index of the literature for nurses and other health professionals (CINAHL), LILACS and Cochrane Central of controlled studies), using the descriptors: heart transplantation, exercise, physiotherapy, physical therapy and physical activity, and no language restriction was imposed for the research, and only the studies developed in the last 16 years were used. Results: 67 articles were found in the initial search. From the 8 articles selected, it was verified that the exercise improved the capacity and the physical performance of individuals in the postoperative period of heart transplant surgeries. Conclusion: Evidence indicates that exercise under the supervision of the professional physiotherapist showed beneficial effects in the rehabilitation of individuals who are in the period after cardiac transplantation.
\end{abstract}

Key words: Heart transplantation; Exercise; Physical Therapy Specialty; Motor activity. 
Heart Failure (HF), a clinical condition characterized by the heart's difficulty in assuring proper cardiac output, is due to risk factors such as coronary artery disease (CAD), systemic arterial hypertension, diabetes mellitus and dyslipidemias ${ }^{1}$. According to DATASUS, there are approximately 2 million patients with HF in Brazil. It is estimated that in 2025, Brazil will have about 30 million elderly people, culminating in the increase of cases and expenses with the syndrome ${ }^{2}$.

Despite the increasing advances in clinical and pharmacological interventions, increase in quality and life expectancy, many individuals with HF persist with evolution refractory to conservative treatment and require cardiac transplantation. According to Mangini and colleagues, cardiac transplantation is aimed at improving the quality of life and increasing survival. Some variables can be used to predict the prognosis of patients undergoing this intervention, such as: oxygen consumption and the equivalent of ventilation of carbon dioxide. In addition, patients with chagasic cardiomyopathy have a worse outcome after surgery ${ }^{3}$.

The physiotherapeutic approach is of great importance in the improvement of physical conditioning, in the optimization of activities of daily living, in the quality of life and in the reintegration of transplanted heart patients in society ${ }^{4}$.

The surgical procedure is invasive, painful and brings numerous common complications that arise in the immediate postoperative period, among them: pain, reduction of cardiopulmonary capacity, cardiovascular deconditioning, reduction of respiratory muscle strength and deficit in airway clearance $^{4}$.

Cardiac deconditioning after surgery is one of the main postoperative complications, with physical inactivity being a frequent problem associated with the lack of knowledge about the benefits of mobilization, fear and absence of family support5. The lack of physical conditioning in pretransplantation, left ventricular diastolic dysfunction and chronotropic incompetence signal the existence of limited physical capacity for the individual with the transplanted heart ${ }^{6}$.

The rehabilitation of patients in the postoperative period of cardiac transplantation occurs through multiprofessional care. Thus, exercise therapy provides recovery and prevention of comorbidities associated with surgical treatment ${ }^{7}$. The rehabilitation of the physical condition depicts a set of actions capable of reducing limitations, guaranteeing functionality and helping to maintain the quality of life.

Given the value of exercises for the preservation of cardiovascular function, it is important to identify standardized guidelines and their treatment-related effects after heart transplantation. Moreover, this theme can still be deepened due to the lack of studies in this population. Thus, this study aims to synthesize the main scientific evidence regarding the effects of different protocols of exercise therapy in patients undergoing heart transplantation.

\section{METHODS}

Search strategy to identify studies

The literature search was performed using the following databases: MEDLINE and EMBASE via Ovid from the period 2000 to October 1, 2016, the accumulated index of the literature for nurses and other health professionals (CINAHL), LILACS and Cochrane Control studies), and no language restriction was imposed for the research, and only the studies developed in the last 16 years were used. The keywords used to search were: heart transplant, exercise, physical therapy, physical therapy and physical activity.

\section{The selection criteria}

Participants in the studies should be 18 years of age or older, in the post-operative heart transplantation, worldwide. The intervention involved the use of physical exercise either aerobic or anaerobic and 
the measures of results should include variables concerning musculoskeletal and metabolic function. We excluded the studies developed in children and those that did not present results based on the analysis of the desired variables. The primary and secondary outcomes of the studies should include objective results such as impact on maximal oxygen uptake, muscle strength, six-minute walk test or any other outcome related to human function.

Randomized clinical trials investigating the effects of physical exercise on post-transplant patients were included. Non-randomized studies, case reports, clinical observations and reviews were excluded.

Extraction of data
Initially, the selection of studies to extract the necessary data was based on the verification of study titles, as well as the analysis of the available abstracts. Subsequently, the full study reports were compared to the pre-established inclusion criteria in order to determine their relevance to the systematic review. Two reviewers, independently and blindly meeting the inclusion and exclusion criteria defined in the research protocol, extracted the data to examine the characteristics of the study, the patients and the possible efficacy of the therapeutic protocols.

To evaluate the methodological quality of the work, the PEDro scale was used, a tool that quantifies the quality of randomized clinical trials or quasirandomized studies.

\section{RESULTS}

After analysis by two researchers, of the 67 studies initially identified, 59 articles were excluded for several reasons, including studies developed in different clinical settings, those that did not use physical exercise as a therapeutic measure, or did not present an appropriate methodological design. The flowchart shown in Figure 1 points to the final details of the selection. After detailed analysis for the development of this review, eight clinical studies were potentially selected, these included the methodological criteria stipulated for the intended outcome.

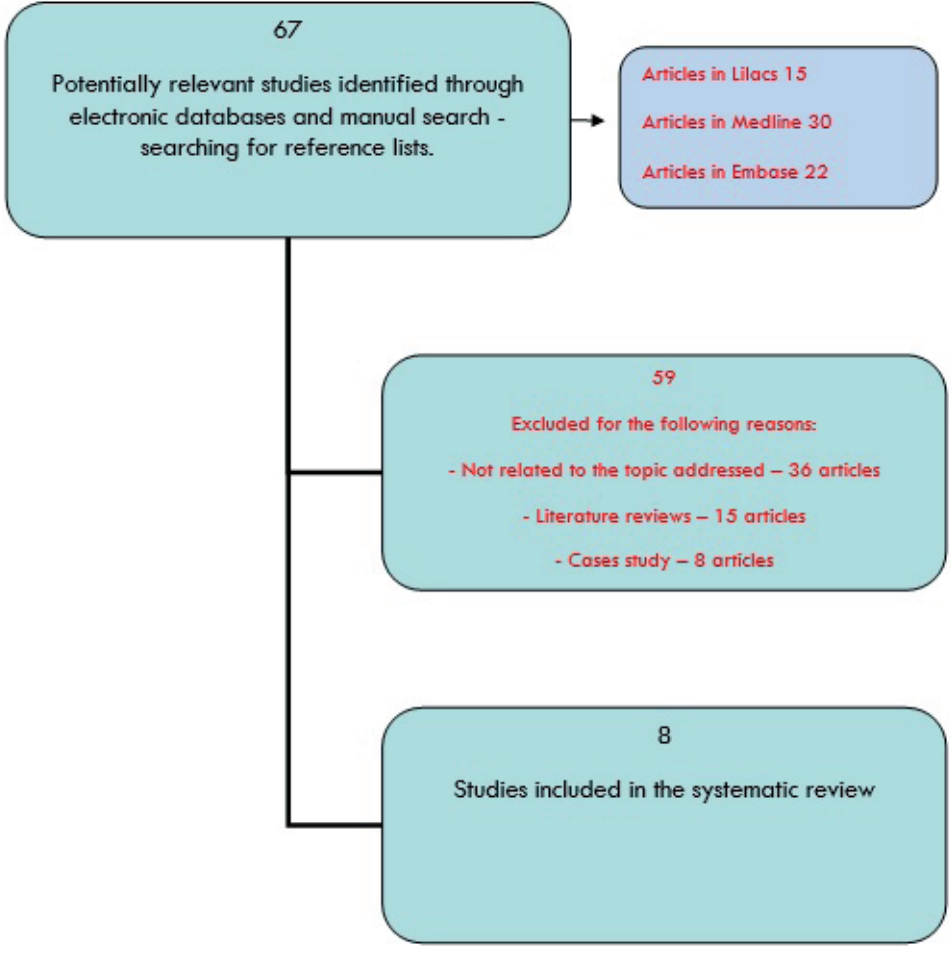


The methodological quality evaluated through the PEDro scale is shown in table 1. All eight studies included in this literature review discuss the use of physical exercise in the post-transplantation of the heart5-12. The sample size ranged from sixteen to forty eight patients of both genders assisted in the most diverse hospital and outpatient units.

Table 01. Stratification of exercise in cardiac transplantation throught the PEDro.

\begin{tabular}{|c|c|c|c|}
\hline Author & Study design & Program & PEDro Scale \\
\hline Kobashigawa ef al. ${ }^{7}$ & Randomized clinical trial & $\begin{array}{c}\text { cycling and upper and lower limb } \\
\text { exercises }\end{array}$ & $04 / 10$ \\
\hline Tegtbur et al. 8 & Randomized clinical trial & exercise program with cycling vs controls & $05 / 10$ \\
\hline Bernardi et al. 9 & Randomized clinical trial & exercise program with cycling vs controls & $05 / 10$ \\
\hline Dall et al. 6 & Randomized clinical trial & high-intensity interval training & $04 / 10$ \\
\hline Karapolat et al. 10 & Randomized clinical trial & $\begin{array}{l}\text { multiple exercises including aerobic } \\
\text { exercise }\end{array}$ & $05 / 10$ \\
\hline Hermann et al. 5 & Randomized clinical trial & $\begin{array}{c}\text { high-intensity interval training vs } \\
\text { controls }\end{array}$ & $04 / 10$ \\
\hline Nytroen et al. 11 & Randomized clinical trial & $\begin{array}{l}\text { high-intensity interval training vs } \\
\text { controls }\end{array}$ & $06 / 10$ \\
\hline Haykowsky et al. ${ }^{12}$ & Randomized clinical trial & aerobic/strength training vs controls & $05 / 10$ \\
\hline
\end{tabular}

Of the eight studies, five demonstrated significant benefits in relation to the application of physical exercise, such as improvement of functional capacity 8-12, increase of muscular strength ${ }^{13}$ and concentration of lactate? One study ${ }^{7}$ did not show any significant statistical difference or clinical significance directly related to the application of physical exercise on functional capacity. Table 2 shows the main clinical trials on the subject and its results.

Table 02. General data of included studies

\begin{tabular}{|c|c|c|c|c|c|}
\hline \multirow[t]{2}{*}{ Author } & Year & & Intervention & Intervention & Results \\
\hline & & $\begin{array}{l}n, \text { mean } \\
\text { age (years) }\end{array}$ & Time & & \\
\hline $\begin{array}{l}\text { Kobashigawa et } \\
\text { al. }^{7}\end{array}$ & 1999 & 27,52 & $\begin{array}{l}\text { Six months } \\
\text { Home training }\end{array}$ & $\begin{array}{l}\text { Bicycle and upper and } \\
\text { lower limb exercises for } \\
30 \text { minutes }\end{array}$ & $\begin{array}{l}\text { Improvement } \\
\text { of physical } \\
\text { capacity }\end{array}$ \\
\hline Tegtbur ef al. ${ }^{8}$ & 2005 & 30,55 & $\begin{array}{l}\text { One year } \\
\text { Home training }\end{array}$ & $\begin{array}{l}\text { Ergometer on alternate days for } \\
\text { one year in } 80-90 \% \text { of maximal } \\
\text { HR }\end{array}$ & $\begin{array}{l}\text { Improvement in exercise } \\
\text { capacity and lactate } \\
\text { concentration }\end{array}$ \\
\hline Bernardi et al. ${ }^{9}$ & 2007 & 24,52 & $\begin{array}{l}\text { Six months } \\
\text { Home training }\end{array}$ & $\begin{array}{l}\text { Bicycle at } 60-70 \% \text { of peak VO2 } \\
\text { for } 30 \mathrm{~min}, 5 \mathrm{x} / \text { week }\end{array}$ & $\begin{array}{l}\text { Improvement in the } \\
\text { performance of } \\
\text { exercise and } \\
\text { control exercised } \\
\text { by the autonomic } \\
\text { nervous system }\end{array}$ \\
\hline
\end{tabular}


Table 02. General data of included studies (continuação)

\begin{tabular}{|c|c|c|c|c|c|}
\hline \multirow[t]{2}{*}{ Author } & \multirow[t]{2}{*}{ Year } & \multicolumn{2}{|r|}{ Intervention } & \multirow[t]{2}{*}{ Intervention } & \multirow[t]{2}{*}{ lesults } \\
\hline & & $\begin{array}{l}n, \text { mean } \\
\text { age (years) }\end{array}$ & Time & & \\
\hline Dall et al. ${ }^{6}$ & 2015 & 16,52 & $\begin{array}{l}12 \text { weeks } \\
\text { Home training }\end{array}$ & $\begin{array}{l}\text { High intensity interval training } \\
\text { and continuous moderate training }\end{array}$ & $\begin{array}{l}\text { Similarity between } \\
\text { training in the } \\
\text { physical } \\
\text { component of } \\
\text { quality of life and } \\
\text { in anxiety markers }\end{array}$ \\
\hline Karapolat et al. ${ }^{10}$ & 2007 & 28,42 & $\begin{array}{l}\text { Eight weeks } \\
\text { Hospital and } \\
\text { home training }\end{array}$ & $\begin{array}{l}\text { One and a half hours of } \\
\text { exercise: aerobic exercise for } 30 \\
\text { minutes at } 60-70 \% \text { of peak } \\
\text { vO2, } 3 x \text { / week }\end{array}$ & $\begin{array}{l}\text { Improvement of } \\
\text { functional capacity } \\
\text { and chronotropic } \\
\text { response in } \\
\text { hospital training }\end{array}$ \\
\hline Hermann et al. 5 & 2011 & 27,50 & $\begin{array}{l}\text { Eight weeks } \\
\text { Home training }\end{array}$ & $\begin{array}{l}\text { Exercise blocks of } 4 \mathrm{~min} / 2 \mathrm{~min} / \\
30 \text { s corresponding to } 80,85 \text { and } \\
90 \% \text { of the VO2 peak, } \\
\text { respectively. }\end{array}$ & $\begin{array}{l}\text { Reduction of } \\
\text { systolic blood } \\
\text { pressure and } \\
\text { improvement of } \\
\text { endothelial } \\
\text { function }\end{array}$ \\
\hline Nytroen et al. ${ }^{11}$ & 2013 & 48,51 & $\begin{array}{l}\text { One year } \\
\text { Home training }\end{array}$ & $\begin{array}{l}\text { Four blocks intervals of } 4 \\
\text { minutes each, performed } \\
\text { in } 91 \% \text { of the peak FC: } \\
\text { with a minimum of three } \\
\text { active recovery periods } \\
\text { between each block. }\end{array}$ & $\begin{array}{l}\text { Improvement in } \\
\text { exercise capacity } \\
\text { and peak VO2 }\end{array}$ \\
\hline taykowsky et al. ${ }^{12}$ & 2009 & 43,59 & $\begin{array}{l}12 \text { weeks } \\
\text { Home training }\end{array}$ & $\begin{array}{l}\text { Continuous aerobic } \\
\text { training at } 80 \% \text { peak } \\
\text { VO } 2,45 \mathrm{~min}, 2 \mathrm{x} / \text { week } \\
\text { and interval training } \\
\text { ergometer for } 30 \text { s at } 90 \text { - } \\
100 \% \text { of peak VO2, } \\
\text { followed by } 60 \text { s rest for } \\
10-25 \text { repetitions, } 2 x / \\
\text { week, at the end of four } \\
\text { Weeks }\end{array}$ & $\begin{array}{l}\text { No } \\
\text { improvement } \\
\text { in left } \\
\text { ventricular } \\
\text { function or } \\
\text { endothelial } \\
\text { function of the } \\
\text { brachial } \\
\text { artery }\end{array}$ \\
\hline
\end{tabular}

Abbreviations: HR - Heart rate; VO2 - Oxygen consumption.

\section{DISCUSSION}

To evaluate the effects of different protocols, the studies used exercise programs at different times postoperatively. Most studies reported demographic data and objective measures. Patient follow-up ranged from six weeks to one year.
The result of this study showed that exercise improved the capacity and physical performance of individuals in the postoperative period of heart transplant surgeries. The total number of participants submitted to heart transplantation ranged from 16 
to 43 patients, being submitted to moderate to high intensity training in the intervention groups.

Karapolat et $\mathrm{al}^{11}$ underwent training in both groups, comparing the hospital and home environment, while Dall et al. ${ }^{7}$ performed in only one group. In both studies, there was a comparison of homeversus-hospital training. The training in the home environment did not obtain significant results in relation to the one performed in the nosocomial environment, due to the fact that the patients did not conduct the exercise program by themselves, in an adequate way. The importance of a supervised and structured program by a physiotherapist with the aim of promoting a better functional capacity and safety during the training of cardiac transplant patients $^{11}$ is highlighted.

The Haykowsky et al. ${ }^{13}$ study, which evaluated the effects of 12 weeks of aerobic training and supervised strength on left ventricular systolic function and endothelial function in transplant recipients during submaximal exercise, presented as one of the main limitations the absence of Measurement of the left ventricular cavity and systolic function.

Hermann et al. ${ }^{6}$ cite that endothelial dysfunction leads to cardiovascular damage and patients usually develop coronary artery disease and endothelial dysfunction, corroborating the idea of Kubrich et al. ${ }^{14}$. The high intensity exercise proposes an increase in maximal oxygen consumption, an improvement in endothelial function and a reduction in systolic blood pressure. Few studies examined the effect of training on vascular function, however, Hermann's work was pioneer in using high-intensity aerobic training in individuals who performed heart transplantation, obtaining significant results with the adult population studied.

In contrast, research has shown that the use of submaximal tests has advantages compared to highintensity tests, presenting greater patient compliance, ease of repetition, safety and greater specificity when related to daily activities and demands ${ }^{15}$.

A randomized, crossover trial ${ }^{7}$ compared the effect of moderate versus high intensity exercise on vascular function, biomarkers, and quality of life in cardiac transplant recipients, and stated that the workouts improved the physical component related to quality of life and anxiety markers, But the sample was small and the study was not designed to analyze changes in endothelial function. Outcomes need to be considered with care and caution.

Two authors ${ }^{17,18}$ report that in the first year after heart transplantation, the autonomic nervous system generally does not exert considerable effects on the heart. Bernardi and collaborators ${ }^{10}$ affirm that after six months of physical training, more efficiency in the autonomic control occurs in the heart as well as in the vascular periphery due to acceleration in the process of cardiac reinnervation and increase in the sensitivity of baroreceptors.

The adaptation of the skeletal muscles and the physical reconditioning course time was evaluated during twelve months, with improvement of the functioning of the skeletal muscle and resistance, according to Tegtbur et al. 9 . In addition, exercise could increase tissue perfusion, mitochondrial density and reduction in the concentration of chemical substances that help to determine the state of cellular oxygenation, such as lactate ${ }^{18}$.

\section{CONCLUSION}

This review identified that structured exercise programs, accompanied by physiotherapists, provide beneficial effects in patients undergoing heart transplantation. The different protocols complicated the comparison between them, in addition to reduced sample and short-term training, in most of the studies. The best protocol is not clearly established in the literature, but should be composed of aerobic and resisted exercises.

On the other hand, despite the limited quality of the studies in the methodological context, the articles included in this systematic review demonstrated that physical exercise seemed to be a safe and well tolerated intervention. Thus, there is a need for randomized clinical trials with more judicious methods for better basing and observation of evidence in this specific group of patients. 


\section{AUTHOR CONTRIBUTIONS}

Cordeiro ALL designed the experimente, obtained, analyzed and interpreted the data, performed the statistical analysis and the critical review of the manuscript. Andrade PHC designed the experimente, wrote the manuscript and performed its the critical review. Petto J was responsible for the critical review of the manuscript.

\section{COMPETING INTERESTS}

No financial, legal or political competing interests with third parties (government, commercial, private foundation, etc.) were disclosed for any aspect of the submitted work (including but not limited to grants, data monitoring board, study design, manuscript preparation, statistical analysis, etc.).

\section{REFERENCES}

1. Pereira GA, Pereira T, Oliveira $M$, Manhães $M$, Barros $L$ et al. Segurança e exequibilidade do teste ergométrico em pacientes com insuficiência cardíaca. Insuf Card. $2012 ; 7(2): 51-55$. Portuguese

2. McMurray JJ, Stewart S. Epidemiology, etiology, and prognosis of heart failure. Heart. 2000;83(5):596-602

3. Mangani S, Alves BR, Silvestre OM, Pires PV, Pires LJT, Curiati MNC et al. Transplante cardíaco: revisão. einstein. 2015;13(2):310-8. doi: 10.1590/S167945082015RW3154

4. Cordeiro AL, Carvalho VO. Abordagem fisioterapêutica no transplante cardíaco. In: Associação Brasileira de Fisioterapia Cardiorrespiratória e Fisioterapia em Terapia Intensiva; Karsten M, Dal Corso S, organizadores. PROFISIO Programa de Atualização em Fisioterapia Cardiovascular e Respiratória: Ciclo 3. Porto Alegre: Artmed Panamericana; 2016. p. $9-32$

5. Bacal F, Souza-Neto JD, Fiorelli AL, Mejia J, MarcondesBraga FG, Mangini S et al. II Diretriz Brasileira de Transplante Cardíaco. Arq Bras Cardiol. 2009;94(Supl 1):16-73

6. Hermann TS, Dall DH, Christensen SB, Goetze JP, Prescott E, Gustafsson F. Effect of High Intensity Exercise on Peak Oxygen Uptake and Endothelial Function in LongTerm Heart Transplant Recipients. American Journal of Transplantation. 2011 ; 1 1(3):536-541. doi: $10.1111 /$ j.1600$6143.2010 .03403 . x$

7. Dall CH, Gustafsson F, Christensen SB, Dela F, Langberg H, Prescott $\mathrm{E}$. Effect of moderate versus high-intensity exercise on vascular function, biomarkers and quality of life in heart transplant recipients: A randomized, crossover trial. J Heart Lung Transplant. 2015;34(8):1033-41. doi: 10.1016/i. healun.2015.02.001
8. Kobashigawa JA, Leaf DA, Lee N, Gleeson MP, Liu H, Hamilton $M A$ et al. A controlled trial of exercise rehabilitation after heart transplantation. N Engl J Med. 1999;340:272-7. doi: 10.1056/NEJM199901283400404

9. Tegtbur U, Busse MW, Jung K, Pethig K, Haverich A. Time course of physical reconditioning during exercise rehabilitation late after heart transplantation. J Heart Lung Transplant. 2005;24(3):270-274. doi: 10.1016/i. healun.2003.12.010

10. Bernardi L, Radaelli A, Passino C, Falcone C, Auguadro $C$, Martinelli $L$ et al. Effects of physical training on cardiovascular control after heart transplantation. Int J Cardiol. 2007; 1 18(3):356-62. doi: 10.1016/i. ijcard.2006.07.032

11. Karapolat H, Eyigör S, Zoghi M, Yagdi T, Nalbangil $S$, Durmaz B. Comparison of hospital-supervised exercise versus home-based exercise in patients after orthotopic heart transplantation: effects on functional capacity, quality of life, and psychological symptoms. Transplant Proc. 2007;39(5):1586-1588. doi: 10.1016/i. transproceed.2007.01.079

12. Nytroen N, Gullestad L. Exercise after heart transplantation: An overview. World J Transplant. 2013;3(4):78-90. doi: 10.5500/wjt.v3.i4.78

13. Haykowsky M, Taylor D, Kim D, Tymchak W. Exercise training improves aerobic capacity and skeletal muscle function in heart transplant recipients. Am J Transplant. 2009;9(4):734-739. doi: 10.1111/i.1600$6143.2008 .02531 . x$

14. Kubrich H, Petrakopoulou P, Kofler S et al. Impacto da coronária disfunção endotelial em resultado adverso a longo prazo após coração transplantação. Transplantation. 2008; 85: 1580-1587

15. Larsen Al, Aarslund t, Kristiansen M, Haugland A, Dickstein $K$. Avaliar o efeito do treinamento físico em homens com insuficiência cardíaca. Eur Heart J. 2001;22:684-9

16. Bengel FM, Ueberfuhr P, Ziegler SI, Nekolla S, Reichart B, Schwaiger M. Avaliação seriada da reinervação simpática após transplante cardíaco ortotópico. Heart Transplantation Circulation. 1999;99:1866-1871

17. Beckers F, Ramaekers D, Speijer L et al. Evoluções diferentes em coração variabilidade da freqüência após o transplante cardíaco: 10 anos de follow-up. Circulation. 2004;78:1523-1531

18. Ferretti L, Marconi C, Achilli L et al. A resposta da frequência cardíaca ao exercício e catecolaminas circulantes em receptores de transplante cardíaco. Pflugers Arch. 2002;443:370-6 